\title{
Parametry okoruchowe ucznia szybko czytającego
}

\author{
Eye-tracking parameters of a speed reading student
}

\author{
Agnieszka ANDRYCHOWICZ-TROJANOWSKA \\ Uniwersytet Warszawski/ University of Warsaw \\ E-mail: a.andrychowicz@uw.edu.pl,
}

\begin{abstract}
The article, being a continuation of the theme, deals with speed reading from the point of view of eye-tracking research. The aim of the article is to present the eye-tracking results of two speed reading secondary school students who took part in the eye-tracking study aimed at analyzing the way Polish secondary school students work with the English textbook material. The presentation of their results bases on fixations and saccades and is contrasted with the results of other non-speed reading students to check if there are any significant differences between the representatives of both these groups of students.
\end{abstract}

Keywords: eye tracking, speed reading, textbook, fixation, saccade, blink

\section{Wstęp}

Kwestię uczniów szybko czytających podejmuję nie po raz pierwszy. Na łamach 20. numeru czasopisma „Lingwistyka Stosowana” ukazał się mój artykuł dotyczący uczniów szybko czytających, a dokładniej - ich uwagi wzrokowej w trakcie pracy z podręcznikiem do nauki języka angielskiego (A. Andrychowicz-Trojanowska 2016a). W artykule tym krótko przedstawiłam samo zagadnienie szybkiego czytania, podstawowe kwestie dotyczące okulografii, jak również metodologię przeprowadzonego badania okulograficznego i wybrane parametry (takie jak czas wykonywania poleceń, liczba fiksacji, całkowity czas fiksacji, liczba sakad, kolejność „wydarzeń wzrokowych") w odniesieniu do dwóch uczniów szybko czytających na tle całej grupy badanych. Niniejszy artykuł jest jego kontynuacją, dlatego też pominę w nim wspomniane i omówione już kwestie, przypominając jedynie te informacje, które są niezbędne dla toku rozumowania przedstawionego poniżej.

Celem niniejszego artykułu jest przedstawienie bardziej szczegółowych danych dotyczących wybranych parametrów okoruchowych, jakie zostały zarejestrowane u dwóch badanych, którzy znali i stosowali techniki szybkiego czytania. Wszelka numeracja badanych jest identyczna z tą zastosowaną we wspomnianym przed chwilą, poprzednim artykule, dzięki czemu możliwe jest porównywanie (zestawianie) danych z obydwu opracowań. Oznacza to, że, podobnie jak w pierwszym artykule, będę korzystała z oznaczenia „ND+SC” (w znaczeniu „bez dysleksji, szybko czytająca”) dla pierwszej badanej osoby, która ukończyła kurs szybkiego czytania i dużo czytała w domu, stosując poznane zasady, ponadto nie cierpiała na dysleksję, oraz z oznaczenia 
„D+SC” (w znaczeniu „,z dysleksją, szybko czytająca”) dla drugiej badanej osoby, która miała zdiagnozowaną dysleksję, a zasady szybkiego czytania samodzielnie zgłębiała i ćwiczyła w domu. Tym samym stosowane dalej oznaczenie ND(1), ND(2)... $\mathrm{ND}$ (13) oznaczać będzie każdego kolejnego (z trzynastu) badanego bez dysleksji, a oznaczenie $\mathrm{D}(1), \mathrm{D}(2) \ldots \mathrm{D}(8)$ - każdego kolejnego (z ośmiorga) badanego z dysleksją.

\section{Szybkie czytanie w obrazowaniu okulograficznym}

Rozważania w tym rozdziale rozpocznijmy od krótkiego przypomnienia kilku kwestii dotyczących szybkiego czytania. Naukowe początki tej tematyki sięgają czasu II wojny światowej, kiedy to zaczęto używać tachistoskop (urządzenie umożliwiające wyświetlanie materiałów wizualnych w bardzo krótkim i ściśle określonym przedziale czasowym) w celu ćwiczenia pilotów samolotów wojskowych w szybkim i bezbłędnym rozpoznawaniu kształtów nadlatujących samolotów. Okazało się wówczas, że w zasadzie każdy jest w stanie nabyć taką umiejętność. Obserwacja ta stała się podstawą do przyjęcia założenia, że skoro oko ludzkie jest w stanie postrzegać z tak ogromną prędkością, to można również znacznie zwiększyć szybkość czytania. Badania nad prędkością czytania pokazują, że średnia prędkość czytania (w języku polskim) to 250 słów na minutę, podczas gdy rekordziści osiągają wynik od 1500 do nawet 3850 słów na minutę (zob. T. Buzan 1999).

Ze względu na to, że okulograf za pomocą specjalnego systemu pomiarowego, który jest podłączony lub zintegrowany z komputerem, rejestruje ruch gałek ocznych, możliwe jest określenie kierunku linii wzroku, a co za tym idzie - możliwe jest stwierdzenie, na co, w jakiej kolejności i przez jak długi czas padał wzrok badanego (zob. np. S. Grucza 2011, K. Holmqvist i in. 2011, A. Duchowski 2007). Takie możliwości techniczne już wiele lat temu zaowocowały szeregiem badań prowadzonych $\mathrm{z}$ wykorzystaniem okulografu. Badania te dotyczyły przede wszystkim ruchu gałek ocznych różnych grup osób podczas czytania. Jedną z takich grup były osoby, które opanowały techniki szybkiego czytania.

Dane okulograficzne bazują na dwóch podstawowych ruchach oka, jakimi są fiksacje i sakady. W tym miejscu przypomnę tylko, że fiksacje są (pozornym) chwilowym zatrzymaniem ruchu gałek ocznych na fragmencie sceny wizualnej, znajdującym się na linii wzroku, natomiast sakady są przeniesieniem wzroku pomiędzy jednym a drugim punktem fiksacji. Każda sakada kończy się fiksacją, w trakcie której rejestrowane są dane dotyczące poziomu pobudzenia fotoreceptorów w siatkówkach oczu, które są następnie przekazywane do mózgu jako informacja o widzianym w tym momencie fragmencie sceny wizualnej (zob. P. Francuz 2013: 104). Innymi słowy, w trakcie fiksacji dochodzi do percepcji informacji. Percepcja taka nie jest możliwa w trakcie trwania sakady ze względu na jej bardzo dużą prędkość.

$\mathrm{Na}$ podstawie opublikowanych wyników badań wiadomo, że osoby czytające sprawnie i szybko (a do takich niewątpliwie należą ci, którzy stosują techniki szybkiego czytania) wykonują krótsze fiksacje, dłuższe sakady, a liczba regresji (tj. powrotów wzrokiem do przeczytanych/odwiedzonych już fragmentów) jest u nich mniejsza niż w przypadku osób czytających wolno. 
Należy jednak stwierdzić, że niewiele rzetelnych badań prowadzono z udziałem uczniów (osób) szybko czytających. Z badań przedstawionych przez M.A. Justa, P.A. Carpentera i M.E.J. Massona (1982, por. także M.A. Just/ P.A. Carpenter 1987) wynika, że osoby szybko czytające często nie są w stanie podać szczegółowych informacji na temat przeczytanego tekstu, jeśli informacje te znajdowały się w obszarach, na których nie wykonali oni fiksacji. U osób czytających w zwykłym tempie fiksacje są dużo częstsze, dlatego też osoby te były w stanie udzielić odpowiedzi na szczegółowe pytania do teksu. Potwierdza to wcześniejsze obserwacje dotyczące tego, że osoby szybko czytające skanują tekst, a nie czytają go słowo po słowie (więcej na ten temat w K. Rayner/ A. Pollatsek 1989; więcej przykładowych badań okulograficznych osób szybko czytających np. w H. Miyata i in. 2012, S. Hawelka i in. 2015).

\section{Badanie}

Ze względu na to, że interesujące nas tu badanie zostało już dość szczegółowo opisane (np. A. Andrychowicz-Trojanowska 2016b), w tym miejscu podam jedynie najistotniejsze informacje dotyczące jego przebiegu i uczestników.

Badanie zostało przeprowadzone w kwietniu 2015 roku w jednym z warszawskich liceów ogólnokształcących. Narzędziem wykorzystanym do przeprowadzenia badania uwagi wzrokowej był okulograf SMI RED 500, który rejestruje ruch gałek ocznych za pomocą systemu zintegrowanego z komputerem. W badaniu wzięło udział 21 uczniów wspomnianego liceum (chłopcy i dziewczęta; płeć nie była czynnikiem różnicującym w badaniu), w tym 8 uczniów ze stwierdzoną dysleksją. Uczniowie reprezentowali wszystkie trzy oddziały szkoły ponadgimnazjalnej (klasa I, II i III), a ich znajomość języka angielskiego odpowiadała poziomowi od Pre-Intermediate do Upper-Intermediate. Jeśli natomiast chodzi o interesujących nas tu uczniów szybko czytających, to należy wspomnieć, że jeden z nich (uczeń bez dysleksji „ND+SC”) ukończył kurs szybkiego czytania i czynnie korzystał z poznanych na kursie zasad (uczeń podkreślał, że dużo czyta w domu), drugi natomiast (uczeń z dysleksją „D+SC”) sam opanował tę umiejętność. Obydwaj uczniowie znali język angielski na poziomie zaawansowanym.

Materiałem wykorzystanym w badaniu był przygotowany przeze mnie (na podstawie analizy wybranych 13 podręczników trzech wydawnictw funkcjonujących na polskim rynku, tj. Oxford, Pearson, Express Publishing, oraz na podstawie wniosków i założeń z pierwszego badania, przeprowadzonego w styczniu 2015 roku) zestaw imitujący strony zeszytu ćwiczeń do języka angielskiego (wykres 1) oraz strony podręcznika do nauki tego języka (podsekcja Reading; wykres 2). 


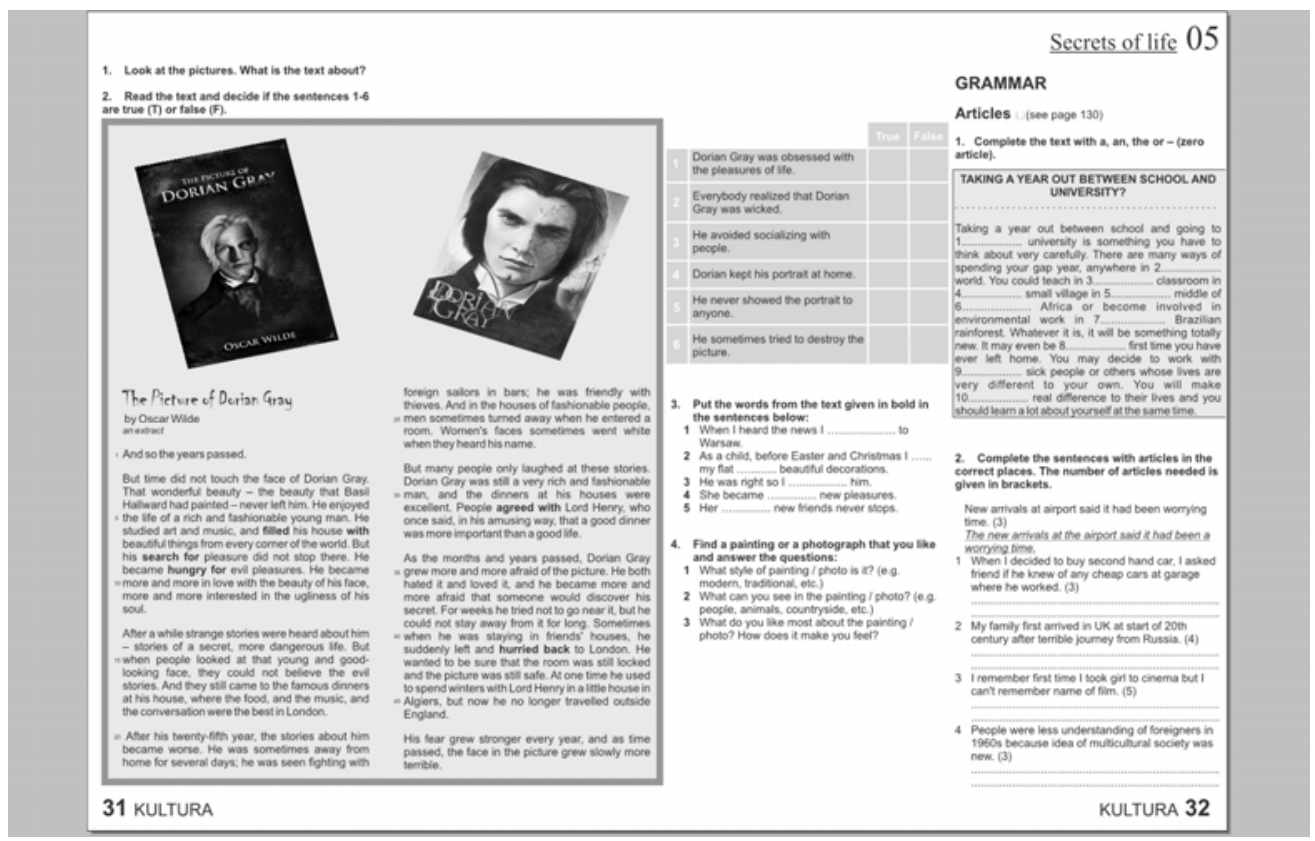

Zdjęcie 1. Materiat czarno-biaty (CB).

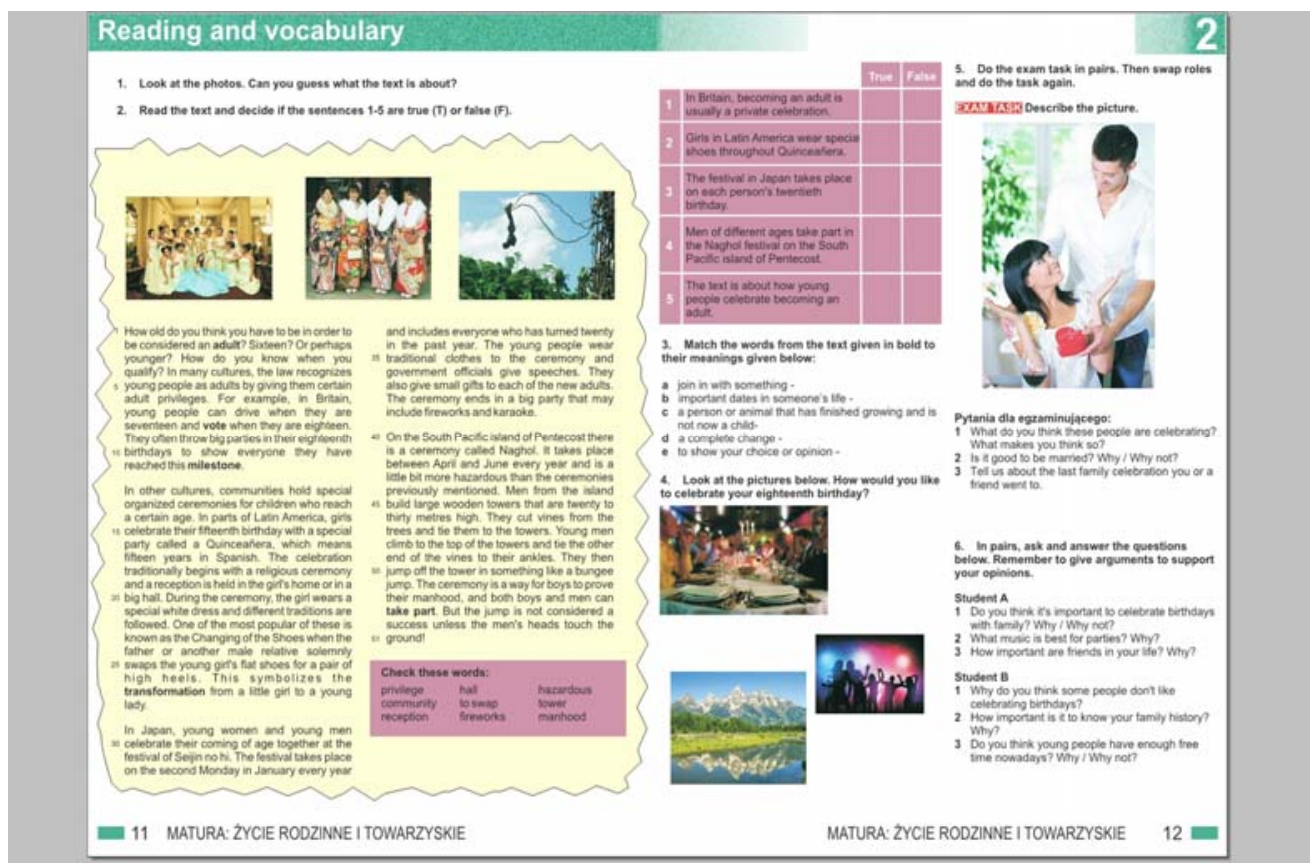

Zdjęcie 2. Materiat kolorowy (KOLOR).

Przed przystąpieniem do badania jego uczestnicy otrzymali podstawowe informacje na temat urządzenia oraz przebiegu badania. Uczestnicy siedzieli w odległości ok. 60 
cm od 22-calowego monitora, do którego dolnej krawędzi przymocowana była minikamera (okulograf). Badanie rozpoczynało się kalibracją okulografu, tj. dostosowaniem urządzenia do specyfiki ruchu gałek ocznych badanego. Następnie na ekranie wyświetlany był materiał czarno-biały (CB), w którym badany miał wykonać zadanie 2 oraz zadanie 3. Po wykonaniu obydwu zadań przez ucznia wyświetlany był materiał kolorowy (KOLOR), w którym badany również miał wykonać zadanie 2, a następnie 3 (czas wykonywania poleceń był nieograniczony, aby nie wprowadzać dodatkowego czynnika stresującego, wpływającego na wyniki). Ruch gałek ocznych był rejestrowany z częstotliwością próbkowania $250 \mathrm{~Hz}$. Ostatnim elementem badania, wykonywanym po zakończeniu pracy z materiałami, było udzielenie odpowiedzi w ankiecie papierowej na pytania dotyczące badania i jego przebiegu.

Należy zauważyć, że długość tekstu do przeczytania w materiale czarno-białym wynosiła 2199 znaków/406 słów, a tekstu w materiale kolorowym 2310 znaków/408 słów. Jednocześnie jednak należy bardzo wyraźnie podkreślić, że materiał wyświetlany na ekranie komputera łączył w sobie elementy tekstowe $\mathrm{z}$ bardzo tu istotnymi elementami kompozycyjno-graficznymi. W związku z tym analizując wszelkie poniższe dane trzeba pamiętać, że nie odnoszą się one wyłącznie do czytanego tekstu, ale do całościowej pracy wzrokiem na wyświetlanym materiale, którego główną częścią był czytany tekst (inny w każdym z materiałów). Tekst ten oraz powiązane z nim zadania skupiły największą część uwagi wzrokowej badanych, ale zamieszczone w nim elementy graficzno-kompozycyjne niejednokrotnie uwagę tę rozpraszały.

W niniejszym artykule zostaną przenalizowane parametry dotyczące indywidualnych charakterystyk okoruchowych, jakie występują u obydwojga szybko czytających badanych (przypomnę, że we wspomnianym już wcześniejszym artykule dotyczącym tych badanych, uwaga w dużym stopniu skupiona była na tzw. obszarach zainteresowania, które tutaj nie są istotne). Parametry te (tj. stosunek liczby fiksacji do czasu pracy z materiałem, średni czas trwania fiksacji, średni czas trwania sakady, średnia amplituda sakady, średnia prędkość sakady, stosunek całkowitej długości sakady do całkowitej długości fiksacji, liczba mrugnięć i stosunek liczby mrugnięć do czasu pracy z materiałem) zostaną przedstawione osobno dla każdego z dwóch materiałów, będących przedmiotem badania (patrz niżej). Na każdym z wykresów zaprezentowane zostaną wartości danego parametru dla każdego z badanych, tak aby łatwo można było porównać z nimi te dla dwóch uczniów szybko czytających. Na każdym wykresie w lewej części osi poziomej przedstawiane będą dane dla wszystkich badanych z dysleksją (od D1 do D8), natomiast w prawej jej części - dla wszystkich badanych bez dysleksji (od ND1 do ND13).

\section{Otrzymane wyniki}

Poniższe dane zostaną zaprezentowane z zachowaniem podziału na dwa podstawowe ruchy gałek ocznych, tj. fiksacje i sakady, oraz na mrugnięcia. W ramach podrozdziału dotyczącego fiksacji i podrozdziału dotyczącego sakad, zostaną przedstawione wybrane i ściśle $\mathrm{z}$ nimi powiązane parametry, które wskażą pewne charakterystyki pracy wzrokiem dwóch uczniów szybko czytających. 


\subsection{Fiksacje}

Ze względu na to, że każdy z badanych wykonał zadane polecenia w różnym czasie (który nie był limitowany), na poniższym wykresie przedstawiam stosunek liczby fiksacji do czasu pracy każdego z badanych.

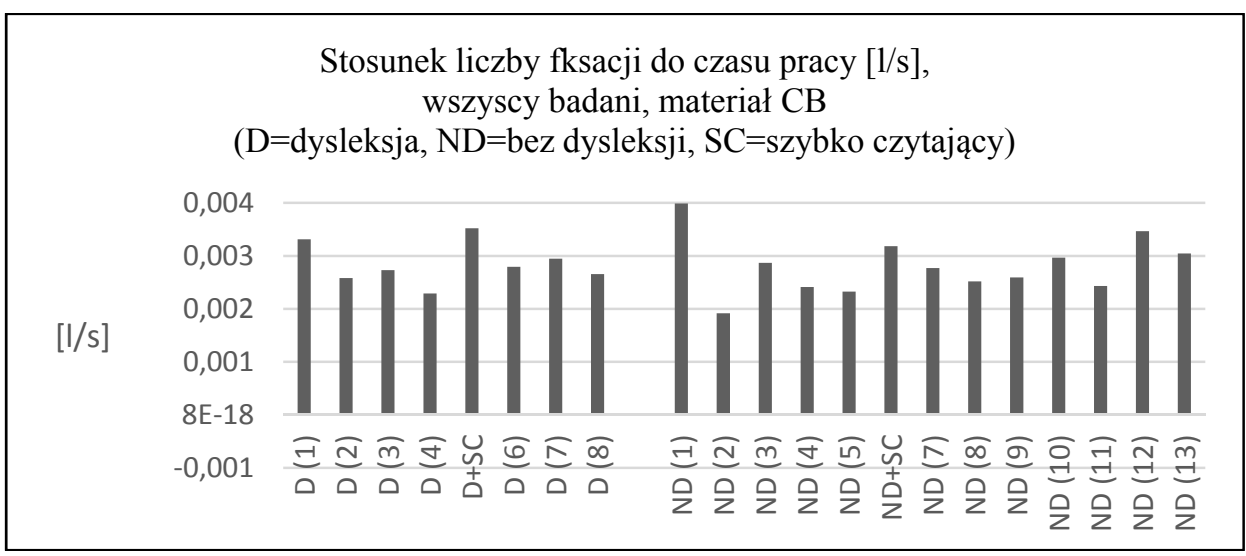

Wykres 1. Stosunek liczby fiksacji do czasu pracy z materiatem czarno-biatym (CB) dla każdego z badanych.

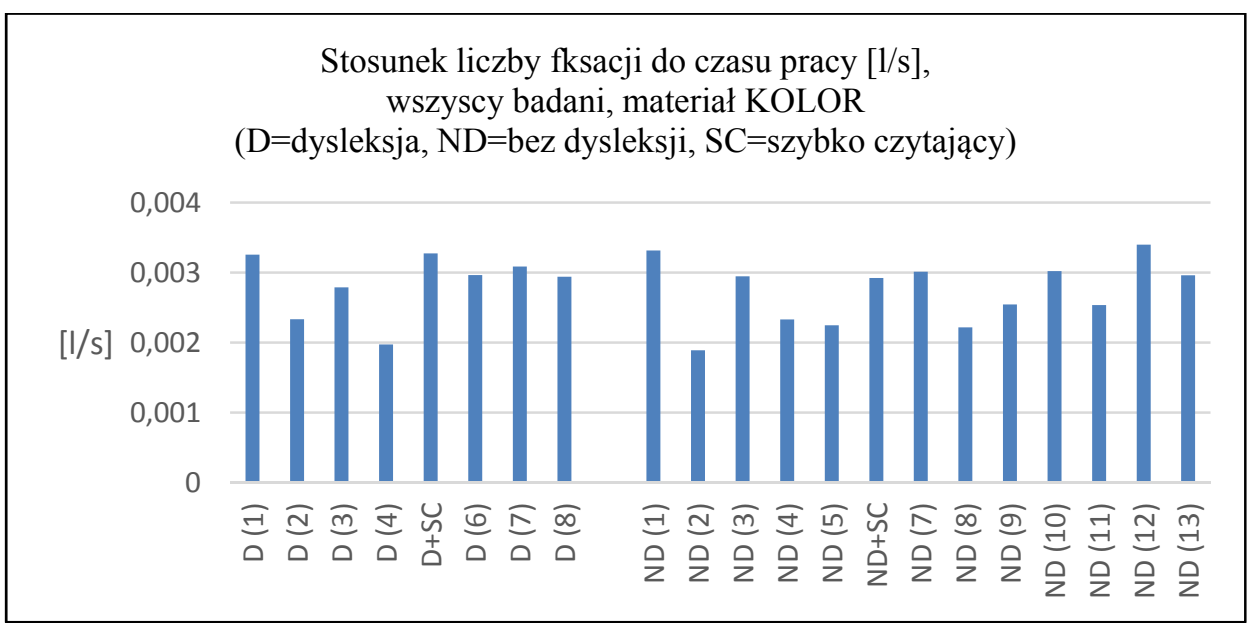

Wykres 2. Stosunek liczby fiksacji do czasu pracy z materiatem kolorowym (KOLOR) dla każdego z badanych.

Na obydwu wykresach (1 i 2) widać, że niezależnie od materiału, z którym pracowali badani, wartości parametru osiągają górne wartości w przypadku obydwu uczniów szybko czytających. Oznacza to, że obydwaj uczniowie wykonywali stosunkowo dużo fiksacji w trakcie pracy z materiałami. Warto także zwrócić uwagę na to, że słupki dla badanego „D+SC” są nieco wyższe niż dla badanego „ND+SC”, czyli ten pierwszy wykonał więcej fiksacji. 
Dwa kolejne wykresy (3 i 4) obrazują średni czas trwania fiksacji. Przyjmuje się, że wartość tego parametru jest powiązana z wysiłkiem poznawczym i przetwarzaniem informacji (np. J.H. Goldberg/ X. Kotval 1999, M.A. Just/ P.A. Carpenter 1976), ponieważ dłuższe fiksacje oznaczają większą trudność $\mathrm{z}$ percepcją informacji (J.A. Renshaw i in. 2004), a to znowu przekłada się na większą złożoność danego zadania dla badanego.

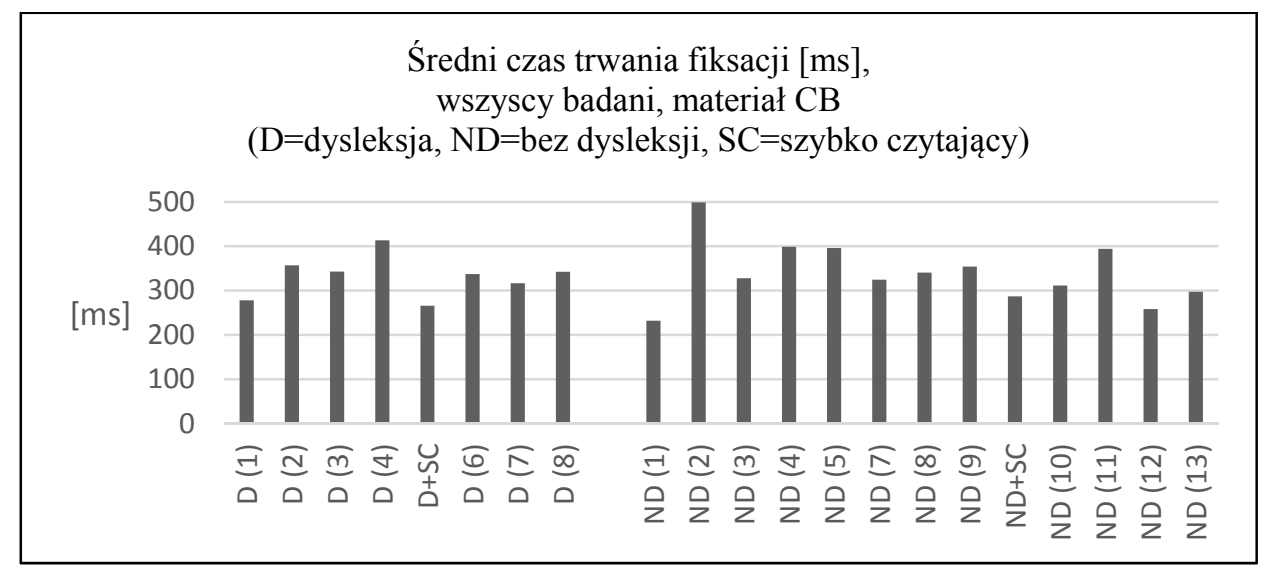

Wykres 3. Średni czas trwania fiksacji [ms] w materiale czarno-biatym (CB) dla każdego z badanych.

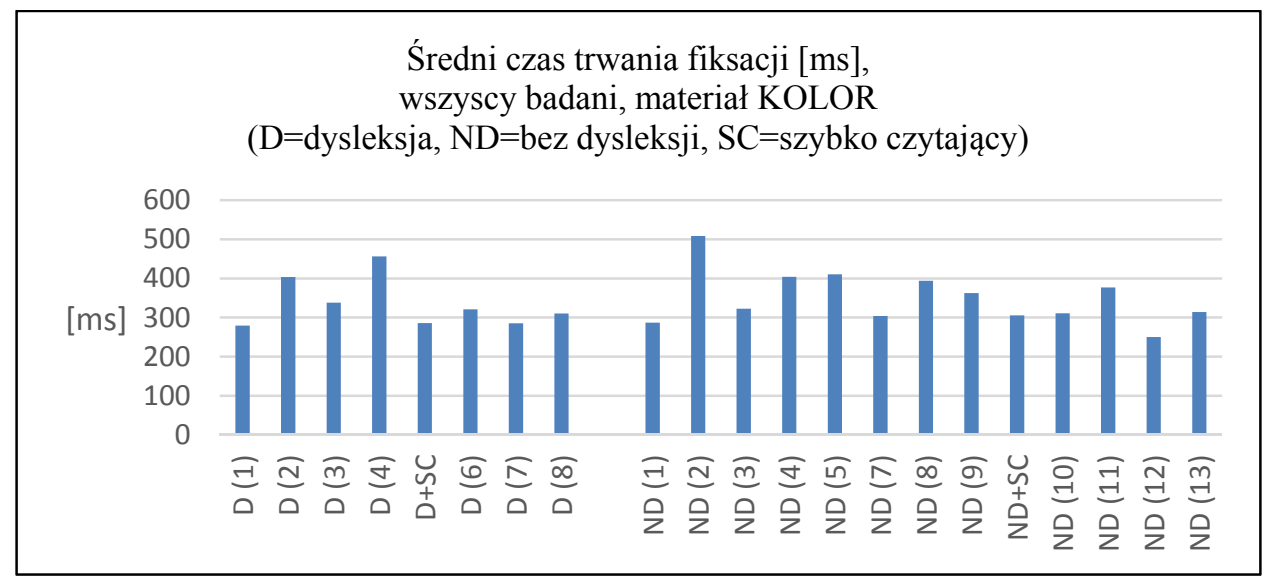

Wykres 4. Średni czas trwania fiksacji [ms] w materiale kolorowym (KOLOR) dla każdego z badanych.

Tym razem widać, że mimo dość dużej liczby wykonywanych fiksacji w stosunku do czasu pracy z materiałami, fiksacje szybko czytających badanych nie są długie wartości parametru dla badanego „D+SC” są jednymi z najniższych w grupie (w materiale czarno-białym mniejsze wartości odnotowano u 2 badanych, tj. $\mathrm{ND}(1)$ i ND(12), a w kolorowym - u 3 badanych, tj. ND(12), D(1), D(7)), a wartości dla „ND+SC" należą do przeciętnych w tej grupie. Najprawdopodobniej oznacza to, że 
badani ci skupiają wzrok na informacji, ale nie wiąże się to z nadmiernym obciążeniem kognitywnym.

\subsection{Sakady}

W trakcie wykonywania sakady nie dochodzi do percepcji informacji, ponieważ prędkość tego ruchu gałki ocznej na to nie pozwala (K. Rayner 1998). Uważa się, że liczba sakad odzwierciedla charakter poszukiwania wzrokowego - im więcej sakad wykonuje badany, tym bardziej poszukuje on informacji w materiale (J.H. Goldberg/ X. Kotval 1999), co oznaczać może gorszy rozkład przestrzenny informacji (J. Grobelny i in. 2006). Ponadto należy pamiętać, że krótsze sakady są bardziej charakterystyczne dla osób czytających słabo, a dłuższe - dla osób szybko czytających, dla których typowe jest skanowanie tekstu. W związku z tym warto przyjrzeć się średniemu czasowi trwania sakady u dwóch uczniów szybko czytających.

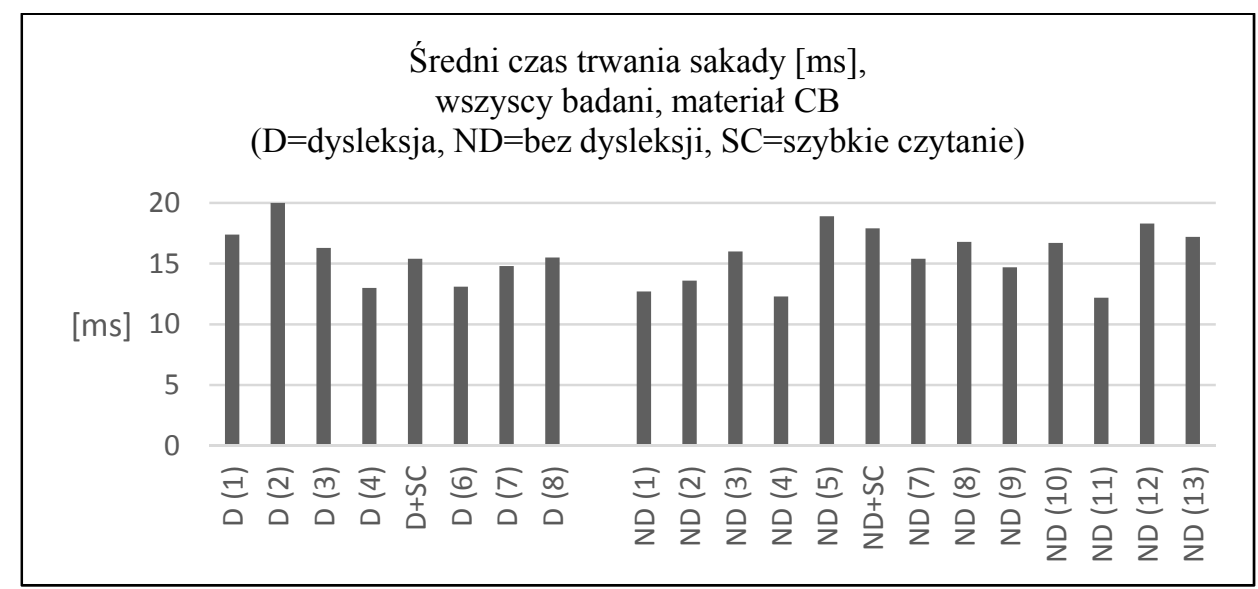

Wykres 5. Średni czas trwania sakady [ms] w materiale czarno-biatym (CB) dla każdego z badanych.

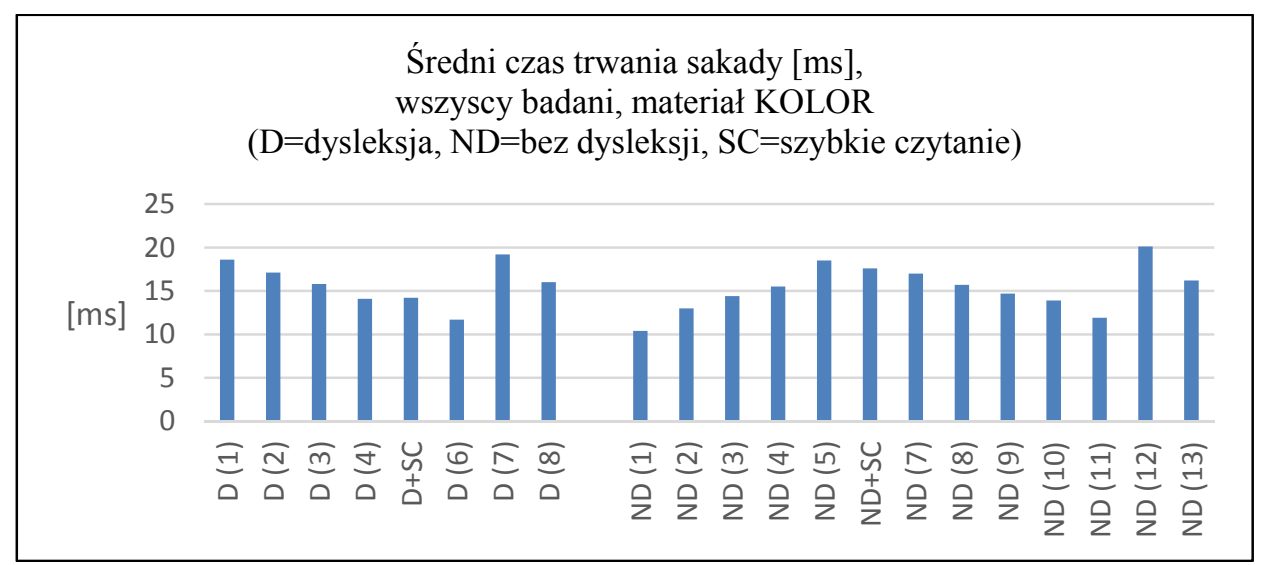

Wykres 6. Średni czas trwania sakady [ms] w materiale kolorowym (KOLOR) dla każdego z badanych. 
Z wykresów 5 i 6 wynika, że sakady szybko czytających badanych trwają średnio dłużej niż przeciętnie w tej grupie, choć żaden $\mathrm{z}$ nich nie osiągnął najwyższych wartości tego parametru. Należy jednocześnie zauważyć, że czasy trwania sakad dla badanego „ND+SC” są nieco dłuższe niż dla badanego „D+SC”. Spostrzeżenie dotyczące tego, że wartości parametru dla badanych szybko czytających w tej grupie nie są najwyższe, choć teoretycznie powinny być, można wythumaczyć tym, że w związku z koniecznością udzielenia odpowiedzi na pytania do tekstu badani musieli czytać go z większą uwagą, zmniejszając skanowanie tekstu wzrokiem, na rzecz zwiększenia stopnia jego zrozumienia. Pamiętać bowiem należy, że konsekwencją stosowania technik szybkiego czytania bywa wspomniane skanowanie tekstu wzrokiem, które polega na wykonywaniu krótkich i niezbyt częstych fiksacji oraz długich sakad, przez co część istotnych informacji umyka, ponieważ nie zostaje na nich skupiony wzrok, a co za tym idzie - nie dochodzi do percepcji tej informacji. Natomiast w przypadku tych dwóch uczniów wydaje się, że technika szybkiego czytania nie prowadzi do wybiórczej percepcji informacji przez nich.

Przyjrzyjmy się kolejnym wykresom:

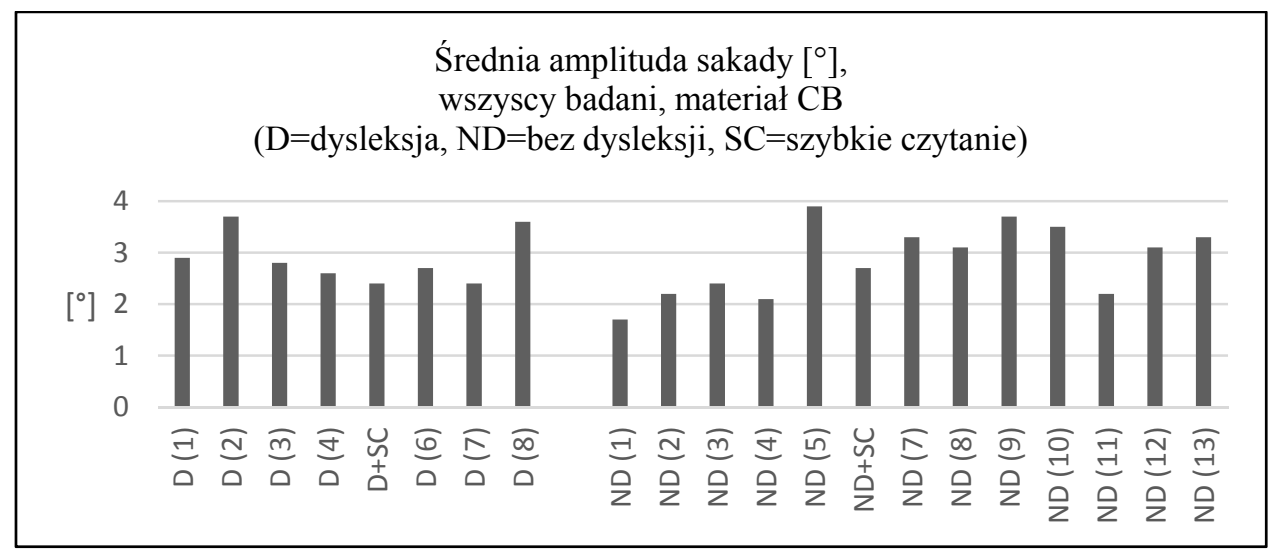

Wykres 7. Średnia amplituda sakady w materiale czarno-biatym (CB) dla każdego z badanych.

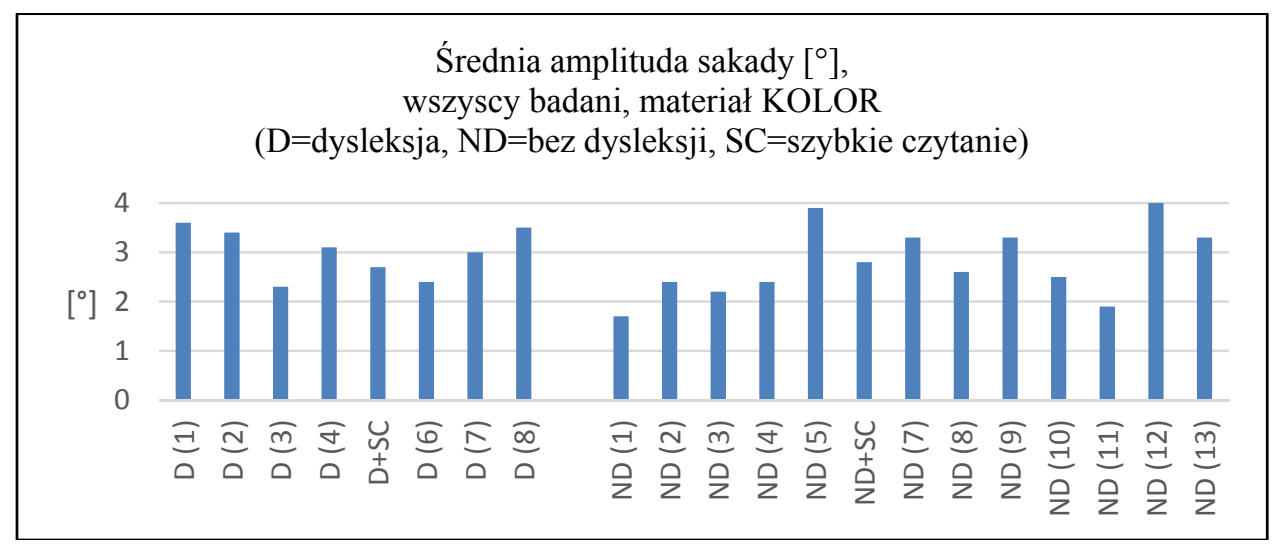

Wykres 8. Średnia amplituda sakady w materiale kolorowym (KOLOR) dla każdego z badanych. 
Amplituda sakady, której średnie wartości zostały przedstawione powyżej, jest jej długością wyrażoną w stopniach. Mniejsza amplituda sakad jest typowa dla osób z dysleksją, osób słabo czytających lub uczących się czytać, co oznacza, że w przypadku osób szybko czytających amplituda powinna być większa.

Z powyższych wykresów wynika, że w przypadku dwóch szybko czytających badanych średnia amplituda sakady dla każdego z nich nie wyróżnia się i osiąga przeciętne wartości w grupie. Wartości dla „D+SC” i „ND+SC” są zbliżone. Długie sakady u niektórych osób mogą mieć związek nie tyle ze sposobem czytania, co stylem pracy przy rozwiązywaniu zadań w materiale podręcznikowym. Możliwe jest bowiem, że duża średnia amplituda sakad jest spowodowana częstym przenoszeniem wzroku w różne rejony strony.

Jeśli natomiast chodzi o średnią prędkość sakady (wykresy 9 i 10), to obydwaj badani plasują się w środku całej grupy, a ich wyniki są do siebie zbliżone.

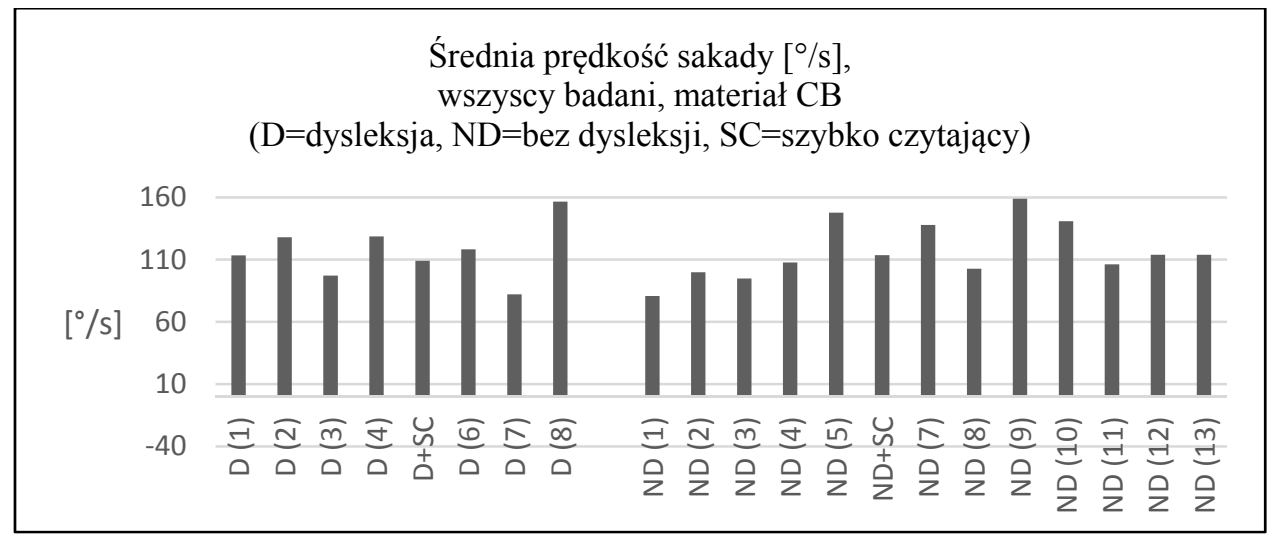

Wykres 9. Średnia prędkość sakady w materiale czarno-biatym (CB) dla każdego z badanych.

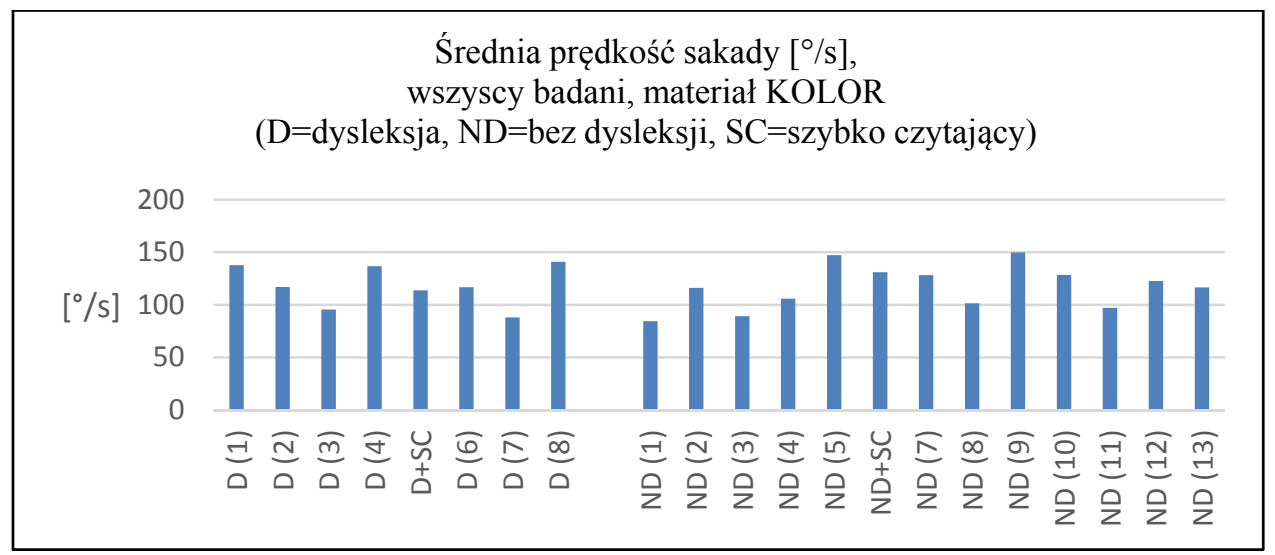

Wykres 10. Średnia prędkość sakady w materiale kolorowym (KOLOR) dla każdego z badanych.

Ostatnim parametrem okoruchowym, na który warto spojrzeć (wykres 13 i 14), jest stosunek całkowitej długości sakad do całkowitej długości fiksacji. Analiza tego 
parametru powinna umożliwić odpowiedź na pytanie o to, jaki ruch gałek ocznych (fiksacja czy sakada) ma największy wpływ na sposób pracy wzrokiem w tego typu materiale.

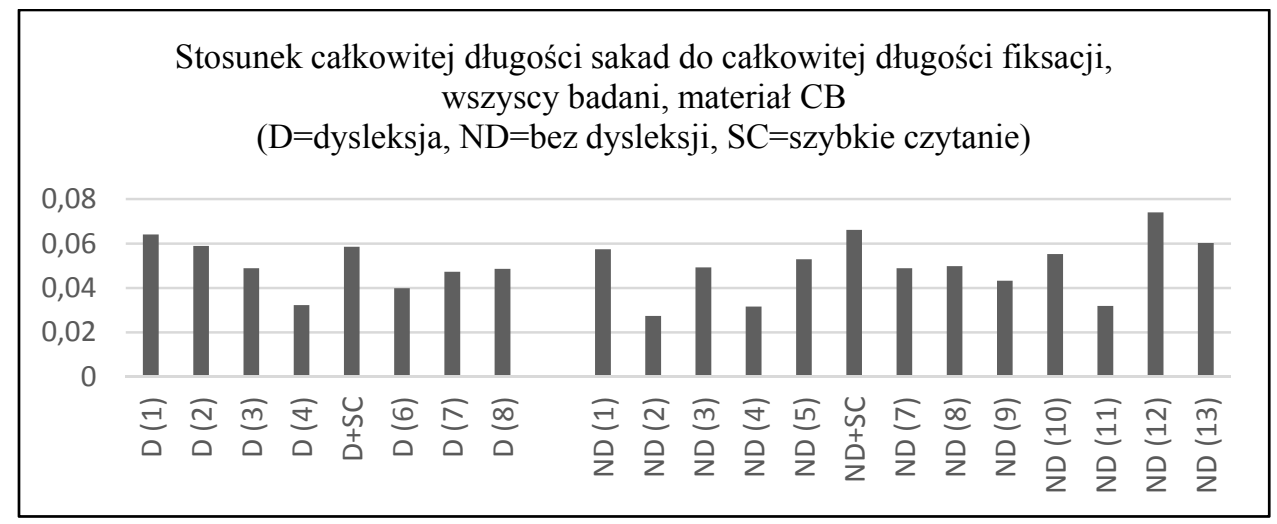

Wykres 11. Stosunek całkowitej dtugości sakad do całkowitej dtugości fiksacji $w$ materiale czarno-biatym (CB) dla każdego z badanych.

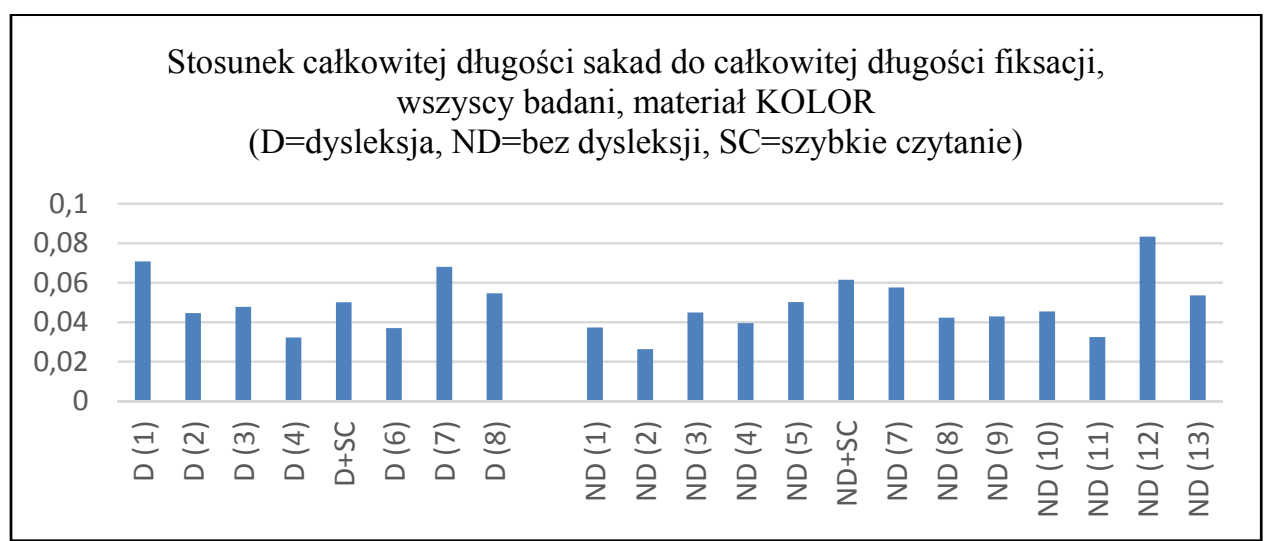

Wykres 12. Stosunek całkowitej dtugości sakad do całkowitej dlugości fiksacji w materiale czarno-biatym $(C B)$ dla każdego z badanych.

Pod względem tego stosunku interesujący nas dwaj badani osiągnęli wartości parametru powyżej średniej. Analizując oddzielne wykresy przedstawiające całkowitą długość sakad oraz całkowitą długość fiksacji (dla obydwu materiałów osobno - wykresy 15-18) można wyprowadzić wniosek o wspomnianym wyżej racjonalnym sposobie pracy uczniów szybko czytających z materiałem. 
Całkowity czas trwania fiksacji [ms], wszyscy badani, materiał $\mathrm{CB}$

$(\mathrm{D}=$ dysleksja, $\mathrm{ND}=$ bez dysleksji, $\mathrm{SC}=$ szybkie czytanie $)$

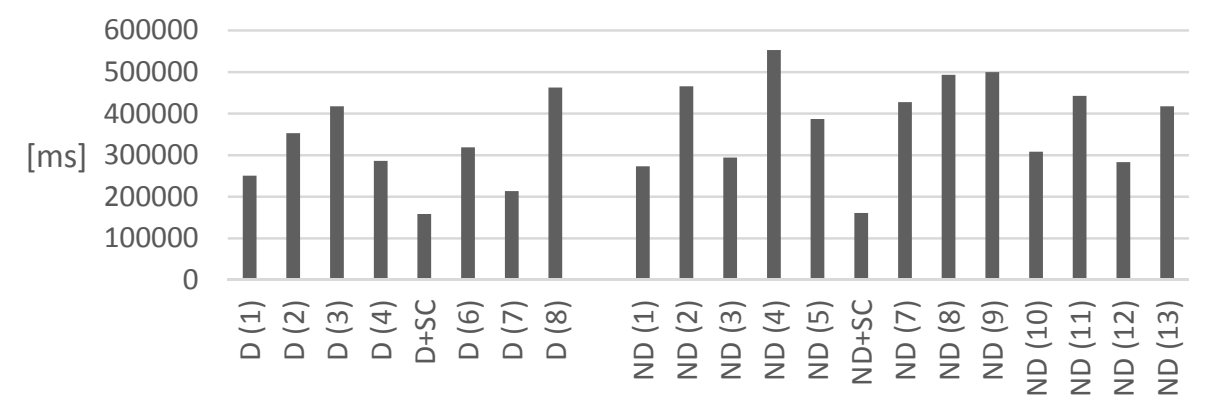

Wykres 13. Całkowity czas trwania fiksacji [ms] w materiale czarno-biatym (CB) dla każdego z badanych.

Całkowity czas trwania sakad [ms], wszyscy badani, materiał $\mathrm{CB}$

$(\mathrm{D}=$ dysleksja, $\mathrm{ND}=$ bez dysleksji, $\mathrm{SC}=$ szybkie czytanie)

30000

25000

20000

[ms] 15000

10000

5000

0

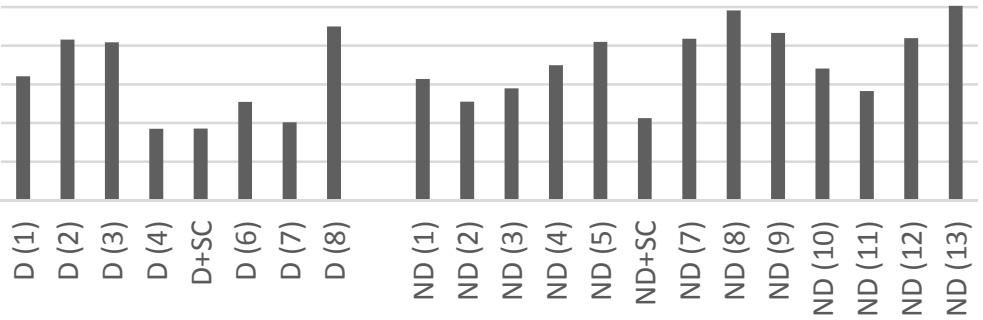

Wykres 14. Catkowity czas trwania sakad [ms] w materiale czarno-biatym (CB) dla każdego z badanych.

Całkowity czas trwania fiksacji [ms], wszyscy badani, materiał KOLOR

$(\mathrm{D}=$ dysleksja, $\mathrm{ND}=$ bez dysleksji, $\mathrm{SC}=$ szybkie czytanie)

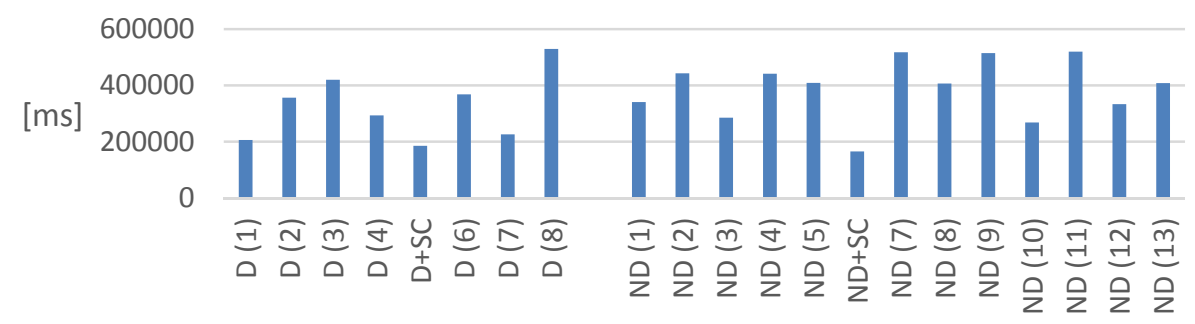

Wykres 15. Całkowity czas trwania fiksacji [ms] w materiale kolorowym (KOLOR) dla każdego z badanych. 


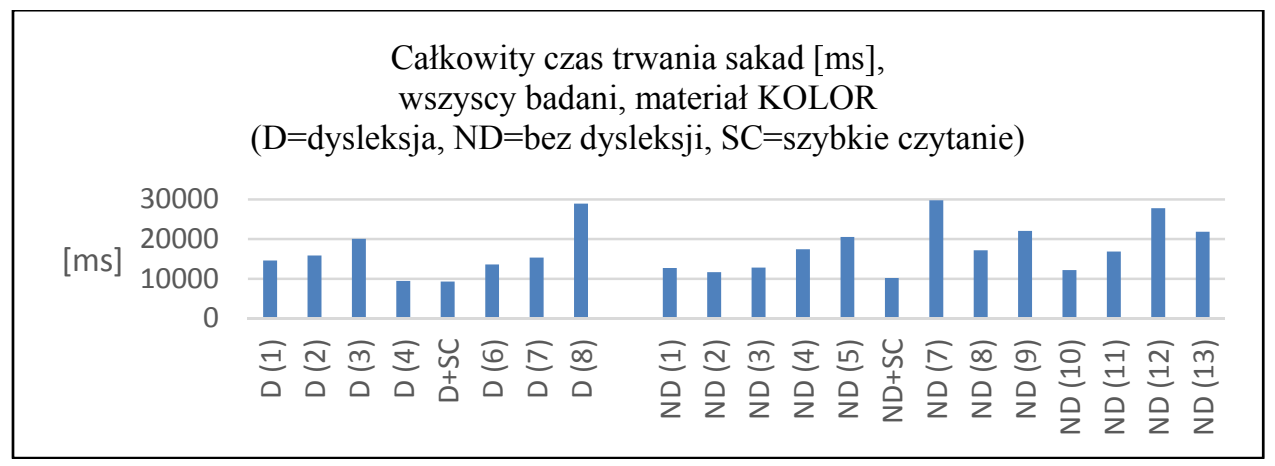

Wykres 16. Calkowity czas trwania sakad [ms] w materiale kolorowym (KOLOR) dla każdego z badanych.

Na wykresach 13-16 widać wyraźnie, że najwięcej czasu podczas pracy z materiałem podręcznikowym zajmują fiksacje, czyli zrozumienie czytanego tekstu (średnio 20 -krotnie). $Z$ tego też powodu średni czas fiksacji i ich liczba mają dominujący wpływ na czas pracy z tekstem.

Podsumowując powyższe można stwierdzić, że szybko czytający badani nie „tracili" czasu na długie skupienia wzroku na elementach materiału, a wykonywane przez nich fiksacje wskazują na percepcję informacji bez zbędnego obciążenia poznawczego.

\subsection{Mrugnięcia}

Ze względu na pewną ciekawość badawczą poniżej krótko przedstawię dane dotyczące liczby mrugnięć. Do tego parametru należy jednak odnosić się z pewną rezerwą, ponieważ, po pierwsze, wyróżnia się trzy rodzaje mrugnięć, tj. odruchowe (mimowolne), które są automatyczną reakcją na jakikolwiek czynnik zagrażający; wolicjonalne (zamierzone), będące reakcją całkowicie świadomą i zamierzoną, mające na celu np. wyrażenie czegoś; oraz endogenne, które są związane z postrzeganiem i przetwarzaniem informacji (J.A. Stern/ D. Dunham 1990, A. Stolińska 2016). Po drugie, każdy człowiek ma swoją własną, zazwyczaj stałą częstotliwość mrugania, która waha się od 3 do 25 razy na minutę. Po trzecie, różne czynniki zewnętrzne, jak na przykład temperatura otoczenia czy wilgotność, mogą wpływać na zmianę tej częstotliwości (M. Andrzejewska/ A. Stolińska 2016, A. Stolińska 2016). Oznacza to, że różne przyczyny mrugnięć oraz tak duże indywidualne zróżnicowanie ich częstotliwości powodują konieczność przyjęcia odpowiednich założeń, a także wykluczenia pewnych czynników z badania, aby móc wyciągać istotne wnioski z danych okulograficznych dotyczących tego parametru. Dlatego też w tym miejscu jedynie pokażę różnice w liczbie mrugnięć.

Uważa się, że częstotliwość mrugnięć, czyli odruchowych bądź zamierzonych zamknięć i otwarć powieki oka, jest powiązana z wysiłkiem kognitywnym i jest do niego odwrotnie proporcjonalna. Oznacza to, że im mniejszy wysiłek poznawczy, tym częstsze mrugnięcia, natomiast częstotliwość mrugania jest mniejsza wtedy, gdy chcemy przyswoić (przetworzyć) więcej informacji wzrokowej (T. Nakano i in. 
2009). Wiąże się to z praktycznym wnioskiem, iż rzadsze mruganie powoduje mniejszą stratę (pominięcie) informacji wizualnej (F.C. Volkmann i in. 1980).

Na poniższych dwóch wykresach (17 i 18) przedstawiony został stosunek liczby mrugnięć do czasu pracy z materiałem dla każdego z badanych.

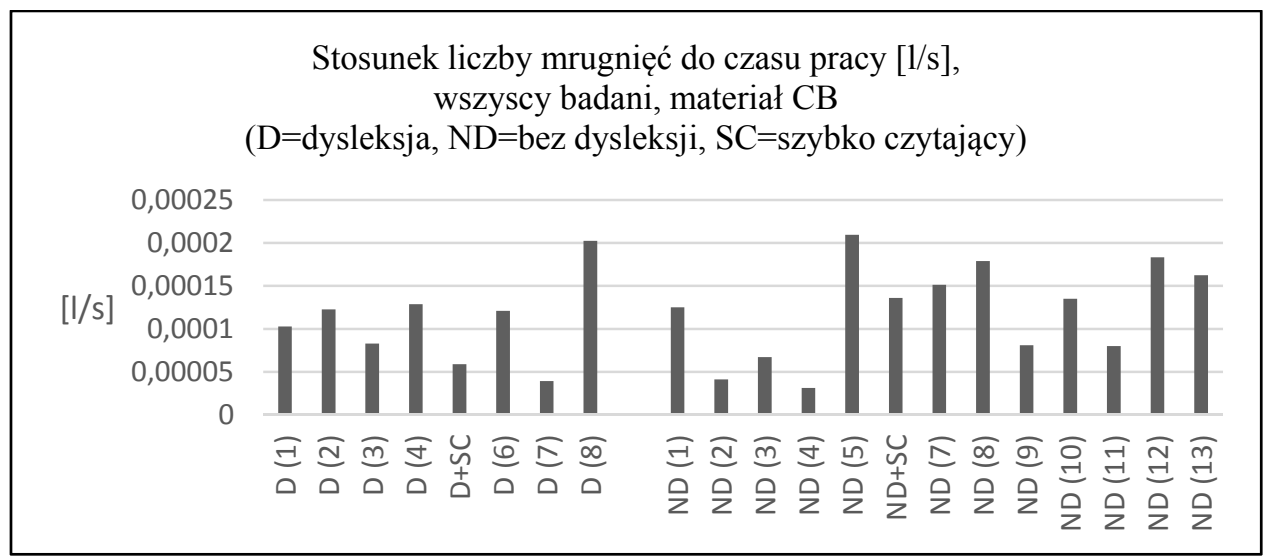

Wykres 17. Stosunek liczby mrugnięć do czasu pracy z materiałem czarno-biatym (CB) dla każdego z badanych.

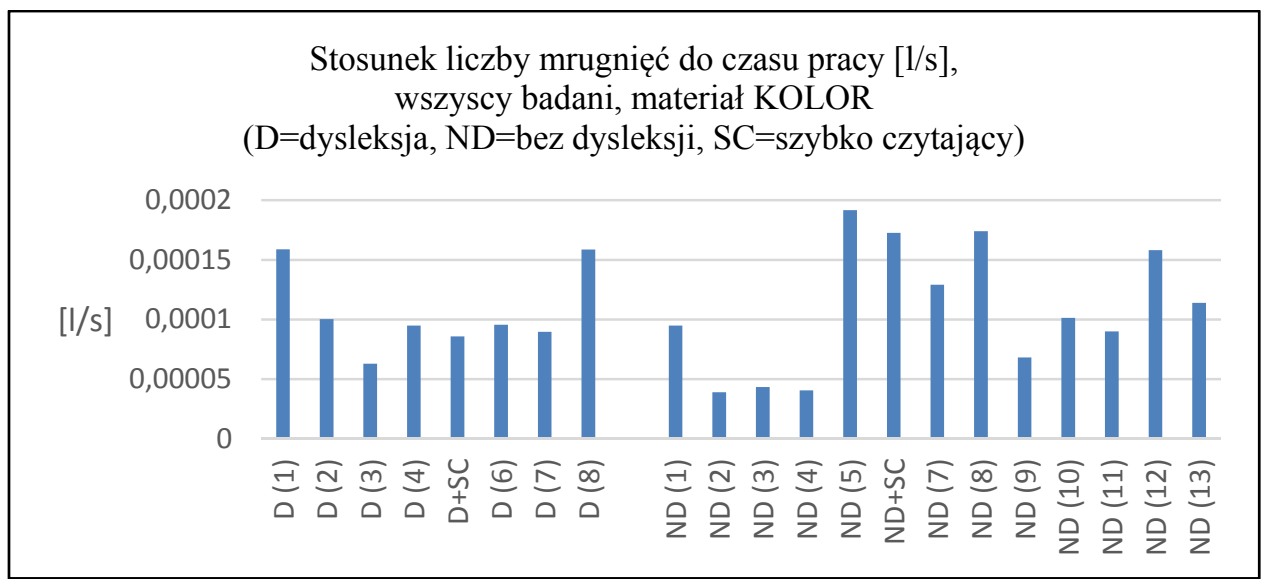

Wykres 18. Stosunek liczby mrugnięć do czasu pracy z materiałem kolorowym (KOLOR) dla każdego z badanych.

Na obydwu wykresach wyraźnie widać duże zróżnicowanie tego parametru pomiędzy wszystkimi badanymi. Jeśli natomiast chodzi o dwóch interesujących nas tu badanych „D+SC” i ,ND+SC”, to pod względem tego parametru zauważalne są wyraźniejsze różnice między nimi. Ten pierwszy w przypadku obydwu materiałów osiągnął niższe wartości, co najprawdopodobniej oznacza większy wysiłek poznawczy, jakiego doświadczył on w porównaniu $\mathrm{z}$,ND+SC”. Jednak na tle całej grupy badanych w materiale czarno-białym „D+SC” osiągnął jedną z niższych wartości (była to jednocześnie druga najniższa wartość w grupie osób z dysleksją), a badany „ND+SC” 
- jedną ze średnich wyższych wartości. Natomiast w materiale kolorowym wartości dla ,D+SC” są na średnim poziomie w grupie badanych z dysleksją, ale także w grupie wszystkich badanych, podczas gdy w przypadku badanego „ND+SC” są one zdecydowanie jednymi z najwyższych nie tylko w grupie badanych bez dysleksji, ale także w całej grupie.

\section{Wnioski}

Podsumowanie przedstawionych danych dotyczących fiksacji prowadzi do wniosku, że pod względem stosunku liczby fiksacji do czasu wykonywania poleceń szybko czytający badani osiągnęli jedne z najwyższych wartości dla obydwu materiałów. W przypadku każdego z materiałów stosunek ten dla „D+SC” był wyższy niż dla „ND+SC”. W przypadku materiału kolorowego „D+SC” osiągnął drugi najwyższy wynik. Jeśli natomiast chodzi o średni czas trwania fiksacji, to należy zauważyć, że badany „D+SC” osiągnął w każdym z materiałów jedne z najniższych wartości, podczas gdy „ND+SC” plasował się pośrodku całej grupy badanych. Oznacza to, że badani ci wykonują dużo krótkich (małych) fiksacji, dzięki czemu nie pomijają informacji zawartych $\mathrm{w}$ materiale, ale też nie wiąże się to dla nich z dużym obciążeniem poznawczym. Ta ostatnia uwaga niewątpliwie wiąże się z wysokim poziomem znajomości języka angielskiego, a w konsekwencji ze stosunkowo dużą łatwością zrozumienia tekstu i powiązanych z nim pytań.

Pod względem parametrów dotyczących sakad obydwaj badani nie odbiegają skrajnie od całej grupy. Średni czas trwania sakady osiągnął średnią wartość w przypadku badanego ,D+SC” i jedną z najwyższych w przypadku badanego „ND+SC” w obydwu materiałach, choć należy zauważyć, że w przypadku pierwszego wartość ta była mniejsza w materiale kolorowym. Wartość średniej amplitudy sakady obydwu badanych znalazła się na środkowym poziomie, choć w każdym z materiałów wyższe wartości rejestrowano u badanego „ND+SC" (w materiale kolorowym wartości te były zbliżone, choć wyższe dla „ND+SC”). W materiale czarno-białym średnia prędkość sakady osiągnęła średnią wartość (i bardzo zbliżoną między sobą) dla obydwu interesujących nas badanych, natomiast w materiale kolorowym była ona niższa dla „D+SC”. W materiale tym wartość dla badanego „ND+SC” była jedną z wyższych, a wartość dla „D+SC” - średnią wyższą. Natomiast pod względem stosunku całkowitej długości sakad do całkowitej długości fiksacji badany „D+SC” za każdym razem osiągnął niższe wartości niż „ND+SC”. W przypadku materiału czarno-białego dla obydwu badanych były to jedne z najwyższych wartości w całej grupie, podczas gdy w przypadku materiału kolorowego wartość dla „D+SC” spadła do średniego poziomu.

Z punktu widzenia stosunku liczby mrugnięć do czasu pracy z materiałami można wyciągnąc wniosek o możliwym większym obciążeniu dla badanego „D+SC" niż „ND+SC” w obydwu materiałach. W przypadku materiału czarno-białego badany „D+SC” wykonał jedną z najniższych liczb mrugnięć, podczas gdy drugi interesujący nas badany - jedną z wyższych, ale nie najwyższą. W trakcie pracy z materiałem kolorowym natomiast liczba mrugnięć u badanego „D+SC” była na średnim poziomie, a u „ND+SC” osiągnęła jedną z największych wartości. Oznaczać to może, że dla 
badanego „ND+SC” praca z materiałami wiązała się z mniejszym obciążeniem poznawczym (warto przypomnieć, że badany ten deklarował, iż dużo czyta w domu; ponadto nie miał stwierdzonej dysleksji). Drugim istotnym spostrzeżeniem jest różnica wartości parametru dla obydwu badanych w jednym i drugim materiale. Wysokości słupków prowadzą do wniosku, że materiał kolorowy był „łatwiejszy” dla badanych niż materiał czarno-biały, ponieważ wyraźnie widać wzrost liczby mrugnięć u obydwojga z nich w materiale kolorowym. Niestety, ze względu na to, że materiały czarno-biały i kolorowy nie były tożsame pod względem treści, nie można wyciągać na tej podstawie wspólnych wniosków uogólniających. Poza tym wskazane byłoby przeprowadzenie podobnych badań na dużo większej grupie badanych, tak aby możliwe było stwierdzenie istotności statystycznej otrzymanych wyników.

Przyglądając się danym zarejestrowanym dla obydwojga szybko czytających badanych należy zatem stwierdzić, że charakteryzują się oni znacznie większą sprawnością $\mathrm{w}$ pracy $\mathrm{z}$ materiałem podręcznikowym, będącym przedmiotem badania. $\mathrm{Na}$ podstawie wniosków przedstawionych we wspomnianym pierwszym artykule na ten temat (A. Andrychowicz-Trojanowska 2016a) można stwierdzić, że interesujący nas dwaj badani stosują techniki szybkiego czytania w sposób racjonalny, który przekłada się na poprawność udzielanych odpowiedzi. Jednocześnie jednak wydaje się, że szybko czytający uczeń z dysleksją skupia nieco więcej uwagi wzrokowej na materiale, z którym pracuje, niż podobny uczeń bez dysleksji.

Kończąc można zatem po raz kolejny zauważyć zasadność wprowadzania technik szybkiego czytania do pracy (glotto)dydaktycznej w szkole. Należy przy tym pamiętać, że techniki takie nie powinny być jedynie zaprezentowane uczniom. Należy je, po pierwsze, z uczniami regularnie ćwiczyć, tak aby weszły im w nawyk, ale, po drugie, również należy uświadamiać uczniom pewne negatywne konsekwencje bezrefleksyjnego korzystania z tych technik. Wydaje się, że dopiero połączenie szybkiego czytania z rozsądnym podejściem do wykonywanego zadania prowadzi do efektywnego i wspomagającego ucznia sposobu pracy.

\section{Bibliografia}

Andrychowicz-Trojanowska, A. (2016a), Uwaga wzrokowa ucznia szybko czytajacego, (w:) „Lingwistyka Stosowana. Applied Linguisics. Angewandte Linguistik” 20, $1-17$.

Andrychowicz-Trojanowska, A. (2016b), Perception of textbook material by dyslectic and non-dyslectic students: an eye-tracking experiment, (w:) „Linguistica Silesiana" 37, 409-427.

Andrzejewska M./ A. Stolińska (2016), Comparing the Difficulty of Tasks Using Eye Tracking Combined with Subjective and Behavioural Criteria, (w:) „Journal of Eye Movement Research" 9 (3), 1-16.

Buzan, T. (1999), Podręcznik szybkiego czytania. Łódź.

Duchowski, A. (2007), Eye Tracking Methodology. Clemson. 
Goldberg, J.H./ X. Kotval (1999), Computer interface evaluation using eye movements: Methods and constructs, (w:) „International Journal of Industrial Ergonomics" 24, 631-645.

Grobelny, J./ K. Jach/ M. Kuliński/ R. Michalski (2006), Śledzenie wzroku w badaniach jakości użytkowej oprogramowania. Historia i mierniki. (URL https://repin.pjwstk.edu.pl/xmlui/bitstream/handle/186319/166/Kansei\%202006_Grobelny.pdf?sequence=1). [Pobrano 29.12.2016].

Grucza, S. (2011), Lingwistyka antropocentryczna a badania okulograficzne, (w:) „Lingwistyka Stosowana. Applied Linguisics. Angewandte Linguistik” 4, 149-162.

Hawelka, S./ S. Schuster/ B. Gagl/ F. Hutzler (2015), On forward inferences of fast and slow readers. An eye movement study, (w:) „Scientific Reports” 5, 1-8.

Holmqvist, K./ M. Nyström/ R. Andersson/ R. Dewhurst/ H. Jarodzka/ J. van de Weijer (2011), Eye Tracking. A comprehensive guide to methods and measures. New York.

Just, M.A./ P.A. Carpenter (1976), Eye fixations and cognitive processes, (w:) „Cognitive Psychology" 8, 441-480.

Just, M.A./ P.A. Carpenter (1987), The psychology of reading and language comprehension. Boston.

Just, M.A./ P.A. Carpenter/ M.E.J. Masson (1982), What Eye Fixations Tell Us about Speed Reading and Skimming (EYELAB Technical Report). Pittsburgh, PA.

Miyata, H./ Y. Minagawa-Kawai/ S. Watanabe/ T. Sasaki/ K. Ueda (2012), Reading Speed, Comprehension and Eye Movements While Reading Japanese Novels: Evidence from Untrained Readers and Cases of Speed-Reading Trainees, (w:) ,PLOS ONE” 7(5).

Nakano, T./ Y. Yamamoto/ K. Kitajo/ T. Takahashi/ S. Kitazawa (2009), Synchronization of spontaneous eyeblinks while viewing video stories, (w:) ,Proceedings of The Royal Society B", 1-10.

Rayner, K. (1998), Eye Movements in Reading and Information Processing: 20 Years of Research, (w:) „Psychological Bulletin” 124, 3, 372-422.

Rayner, K./ A. Pollatsek (1989), The psychology of reading. Englewood Cliffs.

Renshaw, J.A./ J.E. Finlay/ D. Tyfa/ R.D. Ward (2004), Understanding visual influence in graph design through temporal and spatial eye movement characteristics, (w:) ,Interacting with Computers” 16, 557-578.

Stern, J.A./ D. Dunham (1990), The ocular system, (w:) J.T. Cacioppo/ L.G. Tassinary (red.), Principles of psychophysiology. New York, 513-553.

Stolińska, A. (2016), Technika eyetrackingowa w studenckich projektach badawczych, (w:) „Pedagogika”, t. XXV, 347-360.

Volkmann, F.C./ L.A. Riggs/ R.K. Moore (1980), Eyeblinks and visual suppression, „Science” 207, 900-902. 